\title{
Refugees and Border Security Post-September 11
}

\author{
Howard Adel man
}

\begin{abstract}
In the aftermath of the terror attack on the U nited States on 11 September 2001, widespread concerns were raised about security concerns related to access to $C$ anada and the $U$ nited States of refugee daimants. $M$ any new changes were introduced after that event to improve the control mechanisms to reduce the threat of terrorism. In the overlap between refugee and security concerns, particularly with respect to the genuine fear of terrorism, this paper will examine the controls in place and introduced after 11 September 2001 to restrict the entry and retention of terrorists in association with the refugee determination process. This paper will attempt to assess whether the refugee determination process provides any significant opening for terrorists to enter Canada or the U nited States.
\end{abstract}

\section{Résumé}

Dans la période qui a suivi les attentats terroristes du 11 septembre 2001 aux États-U nis, beaucoup d'inquiétudes ont été exprimées autour de la question de sécurité liée à I'entrée au Canada et aux États-U nis de demandeurs d'asile. De nombreux changements ont été introduits à la suite de ces évènements pour améliorer les mécanismes de contrôle et réduire les risques de terrorisme. Dans le chevauchement entre réfugi és et problèmes de sécurité, particulièrement en ce qu'il s'agit de craintes fondées du terrorisme, cet article se propose d'examiner les mesures de contrôle qui ont été instaurées après le 11 septembre, de pair avec le processus de reconnaissance du statut de réfugié, afin de contrôler l'entrée de terroristes et leur détention. L'article essayera de déterminer si le processus de reconnaissance du statut de réfu gié représente réelle- ment une porte d'entrée de quel que importance permettant aux terroristes d'entrer au Canada ou aux ÉtatsUnis.

\section{Security and Refugees}

7 herearemany areas in which immigration and, more particularly, refugee issues overlap with security concerns, especially since the Canadian system of selection and control presumes that the desirable can be distinguished from the undesirable. This overlap with security is particularly important in the case of refugees for, unlike immigrants, Convention refugees are self-selected and are generally permitted to become members of Canada if they can prove that they are entitled to refugee status according to the provisions of the International Refugee Convention. However, even if adjudication has replaced a system of selection, thereare somecontrols in place to assess any security risk related to potential refugee claimants, refugee claimants, and persons given refugeestatus under the Convention. Those who pose security risks are inadmissible. ${ }^{1}$

These controls include: imposition of visa requirements on travelers from specific countries coming to Canada; pre-screening abroad to interdict ${ }^{2}$ undocumented arrivals in partnership with transport companies, ${ }^{3}$ even if genuine refugees are prevented from arriving in Canada to make a claim; limiting the number of refugee arrivals by implementing a "safe third country" mechanism, ${ }^{4}$ a provision al ready in Canadian legislation that eliminates the refugee claims of persons who transited through a country - specifically the U nited States - where they could have made a refugee claim; the use of Advanced Passenger I nformation (API) lists with full reservation details to facilitate interdiction at airport ports of entry by disembarkation teams to detect and prevent entry of improperly documented, un- 
documented, and unwanted arrivals; screening at ports of entry to attempt to identify security risks ${ }^{5}$ in partnership with other countries ${ }^{6}$ with which Canada shares information, ${ }^{7}$ detention ${ }^{8}$ of suspect refugee claimants, subject to review, ${ }^{9}$ without resorting to the current Australian system of detaining all claimants; ${ }^{10}$ pre-screening of refugee claimants by the Canadian Security and Intelligence Service (CSIS) to ensure that they are not security risks; ${ }^{11}$ and, finally, removal ${ }^{12}$ of those refused refugee status or those granted refugee status ${ }^{13}$ if they are deemed to be a security risk. These efforts are enhanced by new high-tech systems to detect security risks, such as the Automated Fingerprint Identification System (AFIS) of Citizenship and Immigration Canada ( $\mathrm{CIC}$ ). To ease the burden on and workload of Immigration Control Officers (ICO), safe travellers can now be expedited through immigration control where the systems are in place by using the CAN PASS, INSPASS, and the new Expedited Passenger Processing System (EPPS), all of which were designed to identify pre-approved low-risk travelers expeditiously.

One foundation of this control system is documentation - passports, visas. and refugee (and immigrant) identity documents. Q uite aside from the controls on refugees, one of the major breaches in the control apparatus involves the fraudulent use of passports. These include $C$ anadian passports: there were 2,200 reported misuses of Canadian passports through fraudulent alteration, theft, borrowing, and obtaining legitimate passports illegally ${ }^{14}$ between 1988 and 2000 , according to a 27 September 2001 report of CIC. In addition, corruption is used to buy visas. ${ }^{15}$ Some also argue that the absence of a system of identity cards for immigrants and refugees, prevalent in continental Europe, has al so been a problem (though such a system is now to be introduced into Canada).

In the application of these enforcement mechanisms, there are always constraints - financial, bureaucratic, legal as well as continuing debates between the degree of discretion permitted and the desire to have all control rules spelled out clearly and unequivocally. While control systems apply to undesirables of many kinds - criminals, trafficked persons, war and other serious criminals, human rights violators - this article is limited to the examination of control mechanisms in place or recently introduced to restrict the entry and retention of terrorists in association with the refugee determination process, though in some situations there are linkages between the control of terrorism and other control issues. For example, in the case of the Tamil Tigers, there have been allegations of linkages between organized crime, money laundering, immigrant smuggling operations and terrorism. ${ }^{16}$ In another example, Ahmed Ressam, the terrorist convicted of planning to bomb the Los Angeles airport, plotted bank robberies and organized the fraudulent use of credit cards. This paper will nevertheless focus on terrorism alone and by and large avoid other issues of control.

Whatever theinherent limitations in any control system, in the aftermath of September 11, widespread charges were made ${ }^{17}$ both in the U nited States ${ }^{18}$ and in Canada ${ }^{19}$ that the Canadian control system was porous and inefficient. In a poll conducted by Léger $M$ arketing in the aftermath of September 11, 80 per cent of Canadians demanded stricter controls over immigration.

H owever, in Chapter 2 of a report entitled $\mathrm{H}$ ands across the Border (henceforth $\mathrm{H}$ ands), ${ }^{20}$ the Standing Committee on Citizenship and Immigration, reporting on the effects of September 11 on border and immigration issues to the H ouse of Commons, concluded: "Evidence to date indicates that theattacks of September 11th werelargely orchestrated and carried out by a group of people who entered the U nited States legally," and had nothing to do with individuals attempting to enter Canada to win status as refugees. ${ }^{21}$ H owever, the Canadian Alliance qualified its overall endorsement of the report as follows: "Capacity creates its own demand, for where there is a weakness it will be exploited. The 'refugee system' continues to beexploited by non-refugees and is a grave security concern." And on December 7, 2001, the Toronto Star headlined its coverage of Hands: "M Ps Urge Crackdown on Refugees." Is the refugee control system porous and a security threat to Canadians, or is this all hyperbolic rhetoric with little relationship to reality, and, even worse, an excuse and cover to introduce stricter controls on the entry of genuine refugees to Canada? The latter is the attitude of most individuals in therefugeesupport community. Thus, whileunequivocally condemning the terrorist attacks on theW orld Trade T owers on 11 September 2001 and recognizing the need to take defensive measures against future attacks, refugee and immigration support groups tend to view the terrorism scare after September 11 as having been used as an excuse to restrict and limit refugee entry into Canada even further and with very little justification.

Are refugees a significant security issue or not?

\section{Actual Security Threats and Refugees}

As everyone knows, the September 11 attack on the World Trade Towers was not the first terrorist attack targeting N orth American peopleand property. O nevery early terrorist attack aimed at civilians was the 1985 bombing of an Air India flight with 325 people, mostly Indo-Canadians, aboard. Another airlineattack on an India-bound planewas just barely averted. Several Canadian Sikhs were recently indicted for the Air India disaster. 
Other groupsinvolved in terrorism have been supporters of the Tamil Tigers in Sri Lanka. M any Sri Lankan Tamils arrived in Canada and were accepted as genuine refugees. CSIS several years ago identified the Liberation Tigers of Tamil Eelam (LTTE) as a terrorist organization guilty of assassinations, suicide bombings, ethnic cleansing, torture and rape. Further, the Security Intelligence Review Committee (SIRC) in its 1999-2001 Report (Ottawa 2000) recommended legislation to criminalize fundraising efforts for terrorist and terrorist front organizations prevalent in Canada. This was picked up in the National Post on 8 September 2001, just prior to September 11, in an article entitled "D efunding Terrorism." In October 2001, regulations were introduced, pending legislation, to block money transfers of terrorist organizations. On 7 November 2001, the Canadian government formally declared LTTE to be a terrorist organization. ${ }^{22}$ Further, CSIS purportedly named theT amil Eelam Society as a front for the LTTE. At the beginning of December 2001, CIC denied further funding to the Tamil Eelam Society of Canada, which provides services to Sri Lankan refugees and migrants on the grounds that the society "was not meeting our requirements," according to the CIC spokesperson, Simon MacAndrew. He did not specify what those requirements were.

N ote that these organizations are not so much involved in global terrorism as in support of homeland insurgency movements (which may include the use of terrorism as a strategy), for which they provide monies, lobbying, public relations, sources of recruitment, and safe havens. However, in addition to the LTTE and various militant Sikh groups from India, ${ }^{23}$ Canada has been used as a conduit for global terrorism as well. Terrorist organizations active in Canada include the al Q aeda network and the Algerian Armed Islamic Group (GIA) ${ }^{24}$ as well as Hamas and Hezbollah, which share some common goals with al Q aeda. ${ }^{25}$ In the 1993 W orld Trade Towers attack in which six people were killed, the chief organizer, Ramzi Yousef, used forged Canadian immigration papers to gain access to the U nited States. He went on to plan to sabotage twelve U.S. planes in the Philippines, but that terrorist attack was foiled.

However, the closest connection to Canada, refugees, and security was another foiled terrorist operation, the planned bombing of the Los Angeles airport. Thanks to alert U.S. Customs officials who discovered explosives in the trunk of Ahmed Ressam's car on 14 December 1999 when he tried to cross into Washington State on a ferry from Victoria, British Columbia, Ressam was captured. Ressam had entered Canada as a refugee claimant from Algeria, but had been unsuccessful in his refugee claim. He returned to Canada on a false passport. H is alleged partner, the Algerian Samir Ait M ohamed, entered Canada in October of 1997 with a false Belgian passport and a fake name. $\mathrm{H}$ e too claimed refugee status, and had a hearing in August 1998 in M ontreal but his claim was also rejected. Though having no employment and living off welfare, he paid rent of $\$ 1400$ per month. Hewas picked up in Vancouver in July 2000 on an immigration warrant as a result of information that came out of the trial of Ahmed Ressam. The United States was not the only target the two had in mind. They planned to place an explosive device in a gasoline truck at the busy Laurier/Park intersection in Outrement, M ontreal, a classy francophone area, because Ressam saw ultraorthodox Jews there due to the proximity of a large $\mathrm{H}$ asidic community. They also planned to set off a bomb on a busy commercial block of Ste. Catherine Street in M ontreal. ${ }^{26}$ $\mathrm{H}$ owever, the major targets have been in the U nited States.

Other than our own safety, as well as our concern for American lives and our many shared values, we have other motives than terrorism itself for focusing on immigration and refugee issues as a security concern.

\section{Economics as a M otive}

Canada and the United States boasted the longest undefended border in the world. The U.S. admits about 530 million people across its border each year, almost 200 million from Canada; eighty million of these cross into the U nited States on land. Prior to September 11, there were only three hundred American agents patrolling the US/Canadian border and only seven hundred customs inspectors. As a result of the North American Free Trade Agreement (NAFTA), trade between the two countries grew from $\$ 116.3$ billion in 1985 to $\$ 409.8$ billion in 2000 . That trade represented 85 per cent of Canadian exports in 2000, up from 60 per cent thirty-five years earlier. At the same time, to become more efficient, industry had instituted just-ontime delivery so that auto assembly plants on both sides of the border would have only from six hours to two days of supplies on hand. About 3.75 million trucks per annum cross the four bridges from Ontario to the U.S., about one half via the Ambassador Bridge, which carries fivethousand trucks per day. BeforeSeptember 11, Canadians and Americans had been moving to integrate their economies even more.

Other than the outpouring of sympathy for Americans post-September 11, effects were most acutely felt at thelong delays at border pointsfor both peopleand goods. Consider that each automobile assembly line produces $\$ 1$ million worth of cars per hour. When backups at the U.S. border create delays of days, the economic impact is enormous. ${ }^{27}$ Thus, efforts were expended in three very different directions. First, the smart-border declaration signed by Can- 
ada's Foreign Minister John Manley and Paul Ridge, the U.S. Director of Homeland Security, included provisions for the long-standing efforts of Canada to create joint customs pre-clearance for commercial cargoes and jointly operated customs facilities at remote border points; Canada Customs and Revenue Agency (CCRA) has introduced a self-assessment program (CSA) to facilitate the movement of low-risk commercial traffic as well as a joint commercial driver registration system. Second, efforts are being made to speed up introduction of the CANPASS system (an automatic pass to allow electronic identification for secure Canadian travellers to return into Canada without being checked by an (CO) and its successor, the Expedited Passenger Processing System (EPPS), the technological means that allow immigration and customs officers at airports to identify pre-approved low risk travelers to create what the Canadian Minister of National Revenue in 1996, David Anderson, dubbed "a hassle-free border for honest travelers and businesses." Third, in addition to making the free flow of goods and services as well as secure travelers across the border easier, reinforced security measures were stepped up along the border dividing Canada and the United States. American agent numbers along the border were tripled in the immediate aftermath of September 11, initially from three hundred to nine hundred and then with the addition of another six thousand Patrol Officers. ${ }^{28}$

\section{Changes in Canadian Controls to Enhance Security}

A number of changes on the Canadian side have been made to enhance security with respect to deal ing with refugees that assume refugees create security problems. Even before September 11, in March 2000 the House of Commons Report, Refugee Protection and Border Security: Striking a Balance, tabled in the House of Commons, connected the security and refugee issues. Further, the Immigration and Refugee Protection Act (IRPA), ${ }^{29}$ includes clauses connecting refugee and security issues. For example, clauses condensing the security certificate protection procedurewere drafted before September 11 (though the Bill received Royal Assent on 1 November 2001 to come into force on June 28, 2002).

The Public Safety Act passed after September 11 includes provisions in Part 9 amendments to the current I mmigration Act for stopping a refugee proceeding if a claimant is discovered to bea member of an inadmissibleclassor under a removal order. In such cases, refugee determination proceedings before the Immigration and Refugee Board (IRB) could be suspended or terminated if there are reasonable grounds to believe that the claimant is a terrorist, senior official of a government engaged in terrorism, or a war criminal. Another amendment allows immigration officers to arrest and detain foreign nationals within Canada who cannot satisfactorily identify themselves in the course of an immigration proceeding, thus enabling $\mathrm{CIC}$ to enforce security concerns whether they arise at the border or within Canada. H owever, $\mathrm{CIC}$ does not have to certify that someone detained was an individual who might facilitate acts of terrorism. Other provisions require airlines to provide information on passengers before arrival. The Act provides stiff increases in penalties for those who engage in human trafficking and smuggling; those convicted would facefines of up to $\$ 1$ million and/or prison sentencesfor life. Finally, the provision for the new independent appeal to those refused refugee status - that had been provided for when Elinor Caplan, the then M inister of Citizenship and Immigration, introduced the new Immigration Act - was suspended by her successor, Denis Coderre.

There have been a number of initiatives to harmonize Canadian and American practices, though none can be said to go so far as harmonizing immigration policies according to George Bush's directive on 29 October 2001 when he ordered his officials to begin harmonizing customs and immigration policies with those of Canada as well as M exico to ensure "maximum possible compatibility of immigration, customs and visa policies." ${ }^{30}$ In addition to visa screening abroad and pre-clearance of flights abroad, two key areas of co-operation between Canada and the United States are in the process of being introduced with respect to refugees - the creation of a common list of countries exempt from visa requirements and the introduction of a safe third-country accord.

A day after Canada and theU .S. signed a joint border and immigration accord in December of 2001, Canada imposed visa requirements on the following eight countries: Dominica, Grenada, Kiribati, Nauru, Tuvalu, and Vanuatu (six small island states), as well as Zimbabwe and H ungary. The island states are used to buy passports or, in the case of $\mathrm{N}$ auru, serve as a holding centre for Australian refugee claimants. H ungary was included because, although a small percentage of Roma have been accepted as refugees, Roma from Hungary continually arrive in Canada to become refugee claimants. However, the inclusion of Zimbabwe supports the fears of the refugee support community since 1,652 Zimbabweans made claims in 2000 and the majority ( 70 per cent) of claimants have been successful. In the news release of 4 December 2001, the then M inister of Citizenship and Immigration, Elinor Caplan, explained that, "The decision to impose a visa for Zimbabweans reflects our concern with improperly documented travellers to Canada." The Canadian High Commissioner to Zimbabwe was quoted in the Zimbabwe Independent that same day as saying the visa was imposed to ensure "that only those 
people with genuine reasons are allowed entry to Canada." But most weregenuine refugees! W ould the Canadian $\mathrm{H}$ igh Commission issue a visa if the applicant in Zimbabwe said that his reason was a desire to make a refugee claim? Is it any surprise that the refugee support community believes that such provisionswould, and were probably intended to, deter the arrival of genuine refugees even though there has been no evidence of a security threat from Zimbabweans?

The biggest worry for the refugee support community has been that the U nited States and Canada have finally agreed to implement the safe third country provision already in Canadian legislation. Since 75 per cent of refugee claimants in Canada arrivethrough the U nited States, refugee support groups either totally oppose its implementation or insist on conditions. For example, Amnesty International, in a press release on $23 \mathrm{M}$ ay 2002, demands that individuals denied access to the Canadian system in accordance with a safe third country agreement not be subjected to the American expedited removal process and summarily removed for want of a valid or suitable documentation, that internment only be employed if necessary but alwaysin accord with international standards and never applied to children, and that those fleeing gender-based violence not be denied access. The Canadian Council for Refugees (CCR) is much more vociferously opposed to introducing a safe third country provision and is running a campaign against its introduction with the misleading title of the "None Is Too M any" provision. ${ }^{31}$

The Chrétien/Clinton Canada-USA Accord on Our Shared Border, of February 1995, included a provision for implementing a safe third country provision. The September 11 attack gave the absence of any true effort in that area a new impetus. On 12 December 2001, Canada and theU.S. signed a J oint Statement of Cooperation on Border Security and Regional Migration Issues, otherwise known as the Smart Border Declaration, ${ }^{32}$ that included a commitment to work towards a safe third country agreement that would significantly reduceor bar access to Canada for refugee claimants passing through the U.S. The agreement stated that,

We plan to develop the capacity to share such information and to begin discussions on a safe third-country exception to the right to apply for asylum. Such an arrangement would limit the access of asylum seekers, under appropriate circumstances, to the system of only one of the two countries.

This provision requires that if claimants passed through a country where they were entitled to make a refugee claim, then they would not be allowed to make a claim in the country of arrival but, instead, would be sent back to that country to make a claim.
While the Citizenship and Immigration M inister, Denis Coderre, was reported in the $2 \mathrm{M}$ ay $2002 \mathrm{Globe}$ and $\mathrm{M}$ ail to have promised that no agreement was possible unless the Agreement "guarantees the United States will treat the asylum seekers much like Canada does," on $6 \mathrm{M}$ ay John $M$ anley, who was charged by the Prime M inister with coordinating all matters related to security with the United States, indicated that a draft agreement was ready and would be signed in June at Kananaskis by George Bush and Jean Chrétien in accordance with the thirty-point action planned agreed upon between the two countries at the end of 2001, which included joint security clearancesfor refugee applicants, coordination of visa policies, sharing of information on passenger manifests, and pre-clearance of exports headed across the border. At the time of this writing, the details of any draft agreement are not available.

There were other changes affecting refugees that did not involve legislative changes or implementation of existing legislation. Paul M artin's 10 December 2001 budget allocated $\$ 395$ million to speed up and enhance refugee and immigration screening. A sum of $\$ 500$ million was set aside for detention ${ }^{33}$ and speeding up the removal process. ( M uch larger amounts - $\$ 1.2$ billion - went into high tech devices to speed up the movement of goods and people, such as thePrimary Automated Lookout System (PALS) for land border passenger traffic, designed to take care of 70 million of the 80 million Canadians who cross the Canadian/American border by land each year, and the Canadian Air Transport Security Authority (CATSA), a new authority set up to oversee security at Canadian airports.) N ew immigrant and refugee claimants would henceforth be required to carry a fraud resistant "M aple Leaf" identity card to be paid for by a $\$ 50$ feecharged to the refugee clai mant. ${ }^{34}$ The cards would be encoded with an identifier, such as a fingerprint, and those carrying thecard would useit at ports of entry or to check in periodically at designated kiosks where they would swipe the card to see if it matched their biometric identifier. The cards would al so beused for medical and welfare purposes to prevent fraud and double-dipping. The CCR submission to the Standing Committee on Citizenship and Immigration of the House of Commons complained about the "excessive and intrusive demandsfor information" from immigrants applying for a permanent resident card because the government had no business asking theseindividuals who their employers were or where they went to school for thelast five years, presumably based on some ostensible security need. The CCR also complained about the lack of a mechanism to apply to the $M$ inister for an exemption and to ensure exemption applications are dealt with in a fair manner with respect to the broad provisions concerning inadmissibility on the 
grounds of security, human rights violations, or participation in organized crime.

The fears about the direction of these reports, legislative initiatives, and budgetary allocations were accentuated for somemembers of ther efugeesupport community when the Supreme Court handed down its ruling on the $M$ anickavasagam Suresh, a forty-five-year-old Tamil citizen of Sri Lanka. Suresh entered Canada on 50 ctober 1990 and was accepted as a Convention refugee on 11 A pril 1991. When Suresh applied for landed status in the summer of 1991, the Solicitor General of Canada and the M inister of Citizenship and Immigration declared him inadmissibleon security grounds, on the grounds that Suresh had been a fundraiser for the LTTE and was, therefore, a member of an alleged terrorist organization. On 18 January 2000, the Federal Court of Appeal ruled that:

It is permissible in defined circumstances to deport a suspected terrorist to a country even though, in thewords of the Convention Against Torture and Other Cruel, Inhuman or Degrading Treatment or Punishment, ... there are substantial grounds for believing that refoulement would expose that person to a risk of torture."35

In effect, refugees could be sent back to potential torture under certain circumstances. After the attack on the W orld Trade Towers, the Supreme Court of Canada rendered a ruling that upheld the right of the government to deport Suresh as long as the government observed procedural proprieties. Amnesty International had all along criticized any policies or court rulings for excluding "serious criminals, terrorists, human rights violators, traffickers and security risks" if they would face serious human rights violations such as torture. Al, in a press release dated $7 \mathrm{~A}$ pril 2002, interpreted the Convention Against Torture to which Canada was a signatory as absolutely forbidding return to a state where the individual "would be in danger of being subjected to torture." The Supreme Court determined that it was wholly within the government's prerogativeto determine whether there was any significant danger as long as proper procedures in making that determination were followed.

In order to assess whether such measures are necessary and appropriate, it is incumbent that the security threat be understood in order to assess its relationship to the refugee process.

\section{Terrorism}

The September 11 events were not the first terrorist attacks aimed at U.S. targets by al Q aeda or its predecessors. The 1983 truck bomb in Beirut, the 1988 crash of Pan American flight 103, the 1989 UTA crash in which 171 were killed, the previous attempt on the W orld Trade Towers in 1993 when six were killed, the 1995 bombing of the Military Cooperation Program building in Riyadh, Saudi Arabia, the 1998 bombings of American embassies in Nairobi and Dar es Salaam, the 2000 attack on the USS Cole in Yemen - all of these had been part of a growing pattern of global terrorism fostered by radical Islamist groups aimed at the U.S. The September 11 attack was simply the most audacious and sophisticated with the greatest loss of lives and property.

In the September 11 attacks when American airlines were hijacked and used as explosive missiles to destroy or attempt to destroy American buildings of great symbolic significance in N ew York and Washington, two targeting the two towers of theW orld TradeCentreand two targeting the Pentagon and possibly the W hite $\mathrm{H}$ ouse, the four teams of terrorists - nineteen men in all ${ }^{36}$ - demonstrated that they had been highly prepared and coordinated. For the success of the attack depended on well structured surveillance, clear and unequivocal decisions and planning, and an effectivelogistic support operation. The terrorists had to have knowledge of airport security and know that transcontinental flights carried a low passenger load on Tuesday mornings but also a high fuel load after takeoff. As we have learned from a number of Hollywood terrorist movies, a well-trained attack team capable of using swift initial violence to intimidate, and to take advantage of past habits during airline hijacking that recommended co-operation rather than resistance, is necessary. It was an operation that required close coordination in time. And it depended on some of the hijackers taking enough flying lessons over time to be able at least to steer these large aircraft towards their pre-selected targets.

All these terrorist attacks have been made up of low tech/high tech combinations. They are high tech when they use explosives that are more compact, more lethal, and easier to make, including turning civilian planes into missiles, but low tech when they employ box cutters to hijack the planes. These terrorists seem to have no moral qualms about killing innocents, including women and children. In some cases, women and children are even targeted. The attacks have increasingly become more brutal and indiscriminate with larger numbers of casualties following a multiple coordinated attack. What is most important, the attackers do not require close direction and supervision, but have become self-guided missiles capable of keeping their focus on their targets after long separations of time and distance from the centre of operation. They are better educated and backed by cadres that number in the thousands in a network with a global reach. M uslim extremists committed to messianic terrorism are behind 90 per cent of these attacks. Intelligence on them is difficult to acquire 
since al Q aeda consists of highly organized teams relatively isolated into tightly closed cells, but whose operations depend on loosely structured networking versus strict hierarchical command and control. In this messianic terrorism, theterrorists believe they areopposing conspiracies of powerful, hostile forces out to destroy and eliminate what they value, while their cause is all-good, all-powerful, and guaranteed victory.

It is one thing to describe and characterize these terrorist attacks on which there is general agreement. It is another to explain them. Commentators generally fall into one of five groups in accounting for this terrorism: (1) those who see this terrorism as an expression of irrationality, ${ }^{37}$ (2) those who view it as an expression of one side of a struggle, a sort of civil war within Islam between tradition and modernity into which the United States has been drawn; ${ }^{38}$ (3) those who see America as the main target because of what America has done in the past; ${ }^{39}$ (4) those who see it as a war of civilization aimed at America because of what America stands for; ${ }^{40}$ and (5) those who see this terrorism not as an act of war, either civil, against a state, or against a civilization, but as a crimeagainst humanity. ${ }^{41} \mathrm{H}$ owever, whatever the explanation or interpretation adopted, they all focus on strategies for attacking the problem in its home base rather than defending against the terrorists through homeland security.

\section{Linking Terrorism and Refugees}

It is clear that terrorism aimed at North America is a real threat and both aggressive and defensive measures must be taken to combat it. Though some of those defensive measures include enhanced immigration controls, there is virtually no evidence linking global terrorism with refugees. Global terrorists have not exploited the refugee determination system to gain access to Canada, though several tried. There is an obvious reason for this. Entering Canada via the refugee stream exposes a refugee claimant to authorities, to a security clearance, to divulging information in filling out a refugee claim form. Any sophisticated terrorist would reasonably be expected to avoid such an exposure. Further, there are far easier options for gaining entry into either Canada or the U nited States.

There is plenty of evidence, however, that indicates that homeland insurgency movements characterized by violence have used the refugee determination system as a way for their supporters to gain entry into Canada and as fronts for organizing support for those insurgent terrorist groups. Actionsareunderway to undercut that diaspora support for insurgency movements abroad that use terrorism as a key tool.
There is even more evidence that the security threat which is real and palpable - has been used as a cover to cut down on the entry of refugee claimants coming to Canada whether through visa controls or through the proposed implementation of a safe third-country system. If there are justifications for this indirect cutback by greater restrictions on access to the system, one of them is not security; the security issue is a rationale rather than a reason.

\section{Notes}

1. Part 3, 14 of the regulations registered June 11 (cf. $\mathrm{CIC}$ web site, online: <http://www.cic.qc.ca>) states that a foreign national or permanent resident is inadmissible, "if the Board determines that the person has engaged in terrorism or b) a Canadian court determines that such persons have been involved in the commission of a terrorism offencein accordance with 34 (1) (c) of the Act." Also inadmissible are those determined by the Board, Canadian courts, or the international criminal court to be guilty of crimes against humanity. According to section 35 (1) (b) of the regulations, prescribed officials from states that persecute their own citizens may not be allowed to enter. These include heads of state, government ministers or members of the governing council, senior advisers, senior civil servants, senior military officers and senior members of the intelligence and security services, ambassadors and senior diplomatic officials, and members of the judiciary.

2. Prior to September 11, Canada had forty-four Immigration Control Officers (ICOs) posted abroad. The December 2001 budget allocated increased funds to deploy additional ICOs abroad, perhaps to be enhanced by posting CSIS and RCM P officers abroad as well.

3. Over the five years preceding September 11, Canada interdicted an average of 6,600 individuals each year and prevented them from travelling to Canada.

4. In the interim, direct-backs - that is, sending refugee asylum applicants back to the U nited States to await an initial hearing - have been used as an alternative to detention when initial checks could not be completed expeditiously, such as when proper documents or a senior Immigration Control Officer (ICO) was not available.

5. This involves profiling based on countries to which they traveled, source countries, employment and non-employment backgrounds, past studies, etc. Cf. the Globe and M ail, 19 September 2001, p. 1, for a story on a CIC document marked, "Protected: Canadian Eyes Only - for Official Eyes Only."

6. The Integrated Border Enforcement Teams(IBETs) have been created as multi-agency cross-border intelligence law enforcement teams to share information and coordinate actions against terrorists, illegal migration, and cross-border criminal activity reinforced by the use of a number of high tech devices.

7. In the one area of overseas intelligence in which Canada has a capacity, signals intelligence or SIGINT, Canadian signals intelligence evidently intercepted encrypted messages among 
international terrorist groups indicating a renewed terrorist assault on the U.S., though CSIS erroneously received the credit. (Cf. Jerry Seper, "FBI Alert Based on Coded M essage," Washington Times, 1 November 2001, and Scott Simmie, "Why Spy Agency Had Key Role in Terror Alert?" Toronto Star, 1 November 2001.) This sharing of information was consistent with the priorities of then Immigration Minister Elinor Caplan, who had said, "We need to be able to develop a network where we share information overseas so that we can better protect our continent" to stop "thosewho poseany kind of security threat from coming to Canada or the U.S. to begin with." (Cf. Allan Thompson of the Ottawa Bureau of the Toronto Star, who also reported on 31 October 2001 that Canada and the U.S. were edging towards establishing a common security perimeter by establishing joint screening procedures to stop security threats at the source.)

8. In the Canadian government $\mathrm{M}$ ay 2002 response to $\mathrm{H}$ ands, the claim was made that detention is only used "when absolutely necessary, i.e. when persons pose a threat to public safety, are considered to bea flight risk, or are undocumented and uncooperative in establishing their identity." (emphasis added, p. 4)

9. In Canada, a review of the circumstances of detainees occurs within forty-eight hours and then again within seven days and every thirty days thereafter.

10. TheU NH CR Guidelines on ApplicableCriteriaand Standards related to the Detention of Asylum Seekers view detention as inherently undesirable and should not be used as a deterrence measure or to punish asylum seekers who have entered a country illegally. The Guidelines forbid the automatic use of detention, and provide that detention only be resorted to in cases of necessity as an exception, and should be imposed on reasonable grounds, and, even then, insist that it should not be unduly prolonged. However, since the "reasonable grounds" include opportunities to verify identity, to determine the elements on which the claim for refugee status is based, cases where asylum seekers have destroyed travel documents or used fraudulent documents, or in cases of security concerns, most cases could easily fall under one of these exceptions even if the procedural safeguards are in place, such as providing detention orders and reasons in the language the detainee can understand, providing access to legal counsel, providing for a review of any decision, and allowing the detainee to challenge the reasons before a review tribunal.

11. SIRC in its 2000-2001 Report (Ottawa, 2001) noted that it could takeup to as long as two years to completea background check on a refugee claimant. As the Report also notes, much of thetime taken up by intelligenceliaison concerns immigration, visa, and refugee clearances. However, in spite of the Global CaseM anagement System of CIC (GCM S) and its Field Operational Support System (FOSS), thelack of coordination among CSIS, CIC, and the RCM P has impeded the proper identification of refugee claimants who aresuspect, according to Adrian Humphries ("Caplan Made Promises She Could
Not Keep," N ational Post, 3 N ovember 2001). The designation of liaison officersfrom CIC, CSIS(SLOS) and the RCM P (LOS) was intended to expedite communication and co-operation. Further, the Canadian government in its $M$ ay 2002 response to $\mathrm{H}$ ands committed itself to fair and equitable treatment, the development of national standards for pre-screening, and the training of officers in cross-cultural understanding.

12. CIC employs 350 inland enforcement officers (IEOs) to investigate, remove, and escort deportees.

13. Including humanitarian cases as well as Convention refugee status, Canada admits about 58 per cent of refugee claimants compared to 52 per cent for the U.S.

14. Bertoliny Eugene, an enterprising student at Concordia University, testified at the trial of Ahmed Ressam (where Ressam was convicted of terrorist activity for trying to bomb LoS Angeles airport) that he had obtained five other passports "easily" in addition to the one he supplied Ressam, and only received $\$ 300$ for each of them. Another supplier testified that passports were very easy to obtain, but he sold them for $\$ 800$ each. TheAlgerian co-conspirator with Ahmed Ressam, Samir Ait Mohammed, using false Canadian passports, allegedly tried to arrange the entry into Canada from Germany of four terrorists who had trained with Ahmed Ressam in al Qaeda camps in Afghanistan.

15. Canada has a much smaller problem of control than the U.S. for we admit only six hundred thousand per year as students, tourists, and business people, while the U.S., with its more universal visa requirement, issues over thirty million visas.

16. In comparing foreign intelligence with domestic intelligence related to control, the only issue that does not overlap is perhaps nuclear proliferation, and in terms of domestic intelligence, even this is a problem when the focus is on non-state actors. All the other issues set forth as priorities by the federal Cabinet in 1991 have a domestic security counterpart relevant to domestic intelligence: international terrorism and ethnic and religious conflict in which the diaspora communities generally are significantly involved. These security priorities are: nuclear proliferation, illegal migration, transnational organized crime, economic espionage, and trade intelligence.

17. A backgrounder, "Canada's Asylum System: A Threat to American Security?" by James Bissett, makes theclaim that the refugee determination system is a security threat. Since Bissett is a former Canadian ambassador and was the Executive Director of Canada's Immigration Servicefrom 1985 to 1990, his charges carry some initial credibility. (Cf. online: <http://www.cis.org/articles/2002/back402.html>.) In the article posted on that site, Bissett says: "Canada has introduced some far-reaching security legislation since the attacks in the United States, but the weakest link - Canada's asylum system - has not been addressed . . . the security of both countries remains vulnerableto a $C$ anadian asylum system that seems designed to openly welcome potential terrorists." 
18. Cf. D.L. Brown, "Attacks Force Canadians to Face Their Own Threat," W ashington Post, 23 September 2001; J. Bagole, et al., Wall Street Journal, 24 September 2001.

19. Cf. Stewart Bell, "A Conduit for Terrorists," N ational Post, 13 September 2001, Diane Francis, "Our Neighbour's U pset over Our Loose Refugee System," Financial Post, 22 September 2001.

20. Canada. Hands Across the Border: Working Together at Our Shared Border and Abroad to Ensure Safety, Security and Efficiency, $\mathrm{H}$ ouse of Commons Standing Committee on Citizenship and Immigration Report (Ottawa, December 2001). The Canadian government response was published in M ay 2002 and is available on the internet, online: <http://www.cic. gc.ca/english/pub/hab/ht/m>.

21. An American IN S Bulletin in October reported that thirteen of the nineteen hijackers entered the U.S. on legal business or a visitor visa; there were no records for the others.

22. See also Ravindra Aryasinha, "Terrorism, the LTTE and the Conflict in Sri Lanka," Journal of Conflict Security \& Development I:2, 2001, 25-50.

23. Other terrorist organizations that use Canada as a base for support, recruitment, funds, and a safe haven for homeland insurgency include the Real IRA and the Kurdistan Workers Party from Turkey (PKK).

24. The Algerian terrorists were linked with al Qaeda by John Solomon, "Authorities Identify Six Terror Centres in US," Jerusalem Post, 18 November 2001, and by Susan Sachs, “M erger Spread al-Q aeda Tentacles," N ew York Times, 21 N ovember 2001. As we shall see, two of the terrorists associated with al Qaeda who have been caught came from the Algerian group. Further, Nizar Ben M uhammad N assr N awar, who killed himself al ong with nineteen others, twelve of whom were German tourists, on 11 A pril 2002 when he used an old refrigerated truck filled with propane to blow up an ancient synagogue in Djerba, Tunisia, was evidently part of the Algerian al Qaeda cell based in Montreal. However, Canadian officials could find no record that he had tried to immigrate to Canada or had applied for refugeestatus. (Cf. Toronto Star, 9 June 2002, A1 and A12.)

25. There were other potential cases involving Palestinians, only a few of which have come to light. For example, just prior to September 11, Ary H ussein came to Canada to file a refugee claim. Heditched his papers beforearriving at Pearson airport and landed behind bars after confessing to having once participated in a kidnapping. (Cf. thereport of Bill Schiller in the Toronto Star on 23 N ovember 2001.)

26. This information became availablein early December 2001 as a result of a freedom of information action launched by the Globe and $M$ ail.

27. AsLunman reported in the Globeand M ail of 170 ctober 2001 , "W aits at U.S. Border H urting Economy, B.C. Premier SaysHe Urges PM to Push for North American Security Perimeter." Kuitenbrouwer in the National Post of 29 October 2001 wrote, "Perimeter will save trade: CEOs - $74 \%$ say we need common security rules as worries mount over access to key market."
28. What was once the longest undefended border was becoming a security barrier. U.S. Border Patrol official Robert Finley, chief agent for a nearly five-hundred-mile stretch of the United States-Canadian border from the Continental Divide in M ontana to N orth Dakota, was quoted in an article by Sam Howe Verhovek in the 4 October $2001 \mathrm{New}$ York Times as saying, "There are all kinds of means to get across the prairie illegally. People use bicycles here; they drive in on snowmobiles. They comeover by horseback." Comparethisto theeight thousand American agentsalongtheU .S.-M exican border. Cf. Sam Howe Verhovek in the 4 October 2001 N ew York Times, wherehe began by contrasting the former focus on preventing people from wading across the Rio Grande or hiking across thescorching desert that borderstheU S.S. and M exico, to a new focus on securing the longest unguarded border.

29. Cf. Canada. Bill C-11: An act respecting immigration to Canada and the granting of refugee protection to persons who are displaced, persecuted or in danger (Ottawa, 1 N ov. 2001). See also Canada. Bill C-36: An Act to amend the Criminal Code, theOfficial SecretsAct, theCanada EvidenceAct, theProceeds of Crime( $M$ oney Laundering) Act and other Acts, and to enact measures respecting the registration of charities, in order to combat terrorism, $37^{\text {th }}$ Parliament, $1^{\text {st }}$ session (Ottawa, 2001).

30. According to Bush's spokesperson, Campbell Clark, as quoted in "Bush Aims to Tighten Continent's Borders - U.S. Bid to $\mathrm{H}$ armonize Immigration and Customs Puts Heat on Chretien" (Globeand Mail, 30 October 2001).

31. Catherine Balfour widely circulated an e-mail calling on all Canadian Council for Refugees (CCR) members and friends to organize a media blitz on U.N. World Refugee Day, June 20, over the prospective "safe third country" agreement with theU.S. NGOs misleadingly dubbed the provision the N one Is Too Many agreement after the bookby the same name by Irving Abella and Harold Troper documenting the efforts of the Canadian Immigration Department during the 1930s and 1940s to keep Jews out of Canada. CCR arguesthat "theevidence shows the United States ISNOT A SAFE THIRD COUNTRY for refugees!" (Cf. online: <http://www.ccr web.net>)

32. Previous meetings, such as Border Vision and the Cross-Border Crime Forum, were movements in this direction.

33. Before September 11, about eight thousand people were de tained by immigration for an average of sixteen days; the U.S. average detention time was twice as long, and twenty times more people were detained, a reflection largely of the activity on the M exican border. Grounds for detention in both countries aresimilar, including: the security risk posed; the fear that the individual will disappear underground; and the need to confirm the identity of the person detained, though Canadais less likely to detain refugees based on the latter need.

34. Provisions for a Permanent Resi dent Card were spelled out in theregulations registered J une 11 al though the official version was not available until June 17 on the $\mathrm{CIC}$ web site, $<$ <ttp://www.cic.gc.ca>. As stated in the regulations, "The implementation of the Act on June 28, 2002, will bring with it theintroduction of the permanent resident (PR) card that will 
provide new and existing permanent residents with clear, secure proof of their status. The PR card will automatically be issued to all permanent residents who are new to Canada as of June 28, 2002. Permanent residents al ready in Canada will be ableto apply for the card thisfall according to a schedulebased on their year of landing. After December 31, 2003, all permanent residents will need the PR card to re-enter Canada after traveling abroad."

35. The Supreme Court did not overturn the second case of Mansour Ahani because the Supreme Court ruled that the government had followed proper procedures in considering him a security risk and weighing the risk of torture upon his return.

36. The theory is that twenty men were intended to hijack the planes, but aFrench-M oroccan flight student, Zacarias M oussouai, was detained by INS on 17 August 2001 because his flight instructor at an Eagan, M innesota, flight school became suspicious because of his persistent efforts in training on flight maintenance operations on the flight simulator.

37. Cf. Bruce Cumings, Professor of History at the University of Chicago. $\mathrm{H}$ is views are articulated in an eessay solicited and distributed by the Social Science Research Council (SSRC) in the United States, entitled "Some Thoughts Subsequent to September $11^{\text {th }}$. Seealso James Der Derian, Professor of International Relations at Brown University and Professor of Political Science at the University of $M$ assachusetts, whose views are represented in an e-essay, also distributed by SSRC, entitled "Before, After, and In Between," as well as in remarks made at a symposium sponsored by the Watson Institute for International Studies at Brown University in the aftermath of September 11 and reprinted in a special issue of Briefings: Perspectives on 9.11.2001 published by the W atson Institute.

38. Cf. Timur Kuran, Professor of Economics and Law, and King Faisal Professor of Islamic Thought and Culture, at the University of Southern California, who offers an economic interpretation in his SSRC e-essay, "The Religious Undercurrents of M uslim Economic Grievances." See also Farish A. N oor of the Institute for Strategic and International Studies (ISIS) in $M$ alaysia who articulates a more cultural interpretation of the civil war within I slam in another SSRC e-essay entitled "The Evolution of 'Jihad' in Islamist Political Discourse: How a Plastic Concept Became Harder."

39. Cf. Mahmood M amdami, Professor of Anthropology at Columbia University, in his SSRC e-essay, "Good M uslim, Bad M uslim: An African Perspective;" and Tariq M odood, Professor of Sociology and Director of the University Centre for the Study of Ethnicity and Citizenship at the U niversity of Bristol, in his SSRC e-essay, "M uslims in the W est: A Positive Asset."

40. Cf. Luis Rubio, General Director of the Centre for Research for Development (CIDAC) in M exico City, in his SSRC e-essay, "Terrorism and Freedom: An Outside View;" and David Held, Professor of Political Science at the London School of Economics, in his SSRC e-essay, "Violence and Justice in a Global Age."
41. Cf. Mary Robinson, the United Nations High Commissioner for H uman Rights; her views are expressed in the USIP PeaceWatch of October/December 2001 (p. 7); see also Thomas J. Bierstecker, Director of theW atson Institute for International Studies and H enry R. LuceProfessor of Transnational Organizations at Brown University, in "Perspectives on 9.11.2001; A Special Issue," Briefings, Summer/Fall 2001. Finally, look at Janet Abu-Lughod, Professor Emerita of the Department of Sociology at the New School in New York City, in her SSRC e-essay, "After theWTC Disaster: TheSacred, theProfane, and Social Solidarity."

Howard Adelman is a Professor of Philosophy at York University in Toronto. Heis also a resident faculty member of the Centre for Refugee Studies. This paper was first presented at a conference entitled "Peacekeeping or Gatekeeping: Canadian Security Policy after September 11," hosted by the York Centre for Security Studies at York U niversity on February 7 and 8, 2002. 